Škola stranih jezika LOGOS, UDC: $811.163 .41 ' 276$ :

Beograd

811.134.2'276

skolalogosbeograd@gmail.com

811.131 .1276

004.738 .5

Originalni naučni rad

\title{
OSNOVNE KARAKTERISTIKE SKRAĆENICA KOJE SE KORISTE U KOMUNIKACIJI PREKO APLIKACIJA
}

SAŽETAK: Zahvaljujući razvoju informacionih tehnologija i digitalnih medija, razmena informacija postaje brža, što se odražava i na pisanje. Korisnici društvenih mreža i aplikacija stvorili su novi jezički trend koji se razlikuje od standardnog jezika. Reč je o neformalnom jezičkom varijetetu čije su odlike uprošćena forma, nepoštovanje normi književnog jezika i upotreba velikog broja skraćenica. Rad se bavi karakteristikama skraćenica koje upotrebljavaju korisnici aplikacija Whatsapp i Viber. U uvodnom delu prikazan je teorijski okvir istraživanja, dok je centralni deo rada posvećen analizi korpusa. Identifikacijom i klasifikacijom najučestalijih skraćenica dobijenih iz korpusa na španskom, italijanskom i srpskom jeziku, pokušali smo da spoznamo koji su njihovi osnovni aspekti i dođemo do zaključka da li među navedenim jezicima postoje sličnosti u mehanizmu građenja i upotrebi skraćenica. Rezultati istraživanja pokazali su da je princip stvaranja skraćenica isti i kod tipološki srodnih jezika (španski i italijanski) i kod jezika koji to nisu (španski i italijanski u odnosu na srpski).

Ključne reči: skraćenice, aplikacije, Whatsapp, Viber, internet, španski, italijanski, srpski.

\section{UVOD}

Pojava mobilnih telefona i mogućnost interakcije putem slanja i primanja kratkih tekstualnih poruka, odnosno SMS-ova (Short Message Service) promenila je način komunikacije u poslednje tri decenije. Komunikacija putem SMS-ova više nije bila uslovljena vremenom ili prostorom, a njen cilj je bio da se prenese (sociolingvistički i komunikativno) razumljiva poruka uz korišćenje minimalnog broja znakova. Naime, slanje poruke bilo je jeftinije od telefonskog poziva, ali je istovremeno bilo i restriktivno, budući da je broj karaktera u SMS-u bio ograničen na 160. Zbog toga su korisnici ovog servisa počeli da upotrebljavaju skraćenice umesto celih reči. Ovakav način komunikacije dozvoljavao je primaocu poruke da, zahvaljujući kontekstu, istu razume, a pošiljaocu da smanji troškove slanja većeg broja SMS-ova. Na taj način stvoren je novi jezik, ili preciznije, jezički varijetet tipičan za ovakvu vrstu komunikacije. Budući da je ovaj novi jezički varijetet 
nastao kao alternativa govornoj interakciji, ne iznenađuje činjenica da su se pravopisna i gramatička pravila često zanemarivala, u korist brže i neposrednije komunikacije. Stoga je ovu specifičnu i neformalnu pisanu komunikaciju odlikovala sintetičnost u izražavanju, derivacija novih reči ili hibridnih oblika $i$ korišćenje skraćenica. ${ }^{1}$

Ubrzani razvoj tehnologije i rasprostranjenost interneta na globalnom nivou doprineli su promeni načina komunikacije ljudi, ${ }^{2}$ a time i jezika koje se prilagodio novim okolnostima i potrebama svojih korisnika. Interakcija ljudi preko elektronske pošte, SMS-ova, aplikacija, blogova, foruma i sl. stvorila je nove oblike diskursa, identiteta i jezika (Kern 2006: 183). Internet je omogućio korisnicima četova, različitih društvenih mreža i aplikacija na pametnim telefonima da šalju poruke potpuno besplatno i bez ograničenja broja karaktera $u$ okviru jedne poruke. Ipak, tendencija da se komunicira uz korišćenje skraćenica ostala je prisutna do danas kao jedna od specifičnosti jezika koji se koristi na aplikacijama. Verujemo da razlog ove pojave, budući da nije više u pitanju ušteda novca, leži u činjenici da korisnici imaju potrebu da poruku saopšte brzo, efikasno i uz minimalan trud. Saglasni smo sa Radić Bojanić (2007) koja ističe da učesnici tokom elektronske komunikacije žele da prenesu što veći broj informacija sa što manje napora. Kucanje cele reči ili rečenice zahteva pritiskanje dodatnih tastera i podrazumeva više vremena i truda, što može usporiti komunikaciju, jer se ovakva vrsta interakcije obično obavlja u realnom vremenu. S druge strane, jezgrovitost $\mathrm{i}$ konciznost poruke, jezička ekonomija i brzina mogu negativno uticati na interpunkciju, gramatiku i sintaksu.

Lingvisti imaju podeljene stavove o tome na koji način upotreba skraćenica u ljudskoj interakciji na internetu utiče na jezik, koji je bez sumnje produkt kreativnosti mladih. S jedne strane, pojedini istraživači (Thurlow 2003, Thurlow et al. 2004, Sirah \& Ullah 2007, Rosen et al. 2010, Eco 2011,

\footnotetext{
${ }^{1}$ Na primer, u SMS-ovima koju su ograničeni na 160 karaktera, pravilna upotreba akcenata dovodi do smanjivanja ukupnog broja znakova koji su korisniku na raspolaganju za pisanje poruke. Stoga korisnici ovog servisa žrtvuju akcenat i pribegavaju skraćenicama, izostavljajući one karaktere za koje veruju da čitalac može da predvidi zahvaljujući kontekstu.

2 Baron navodi da je tzv. CMC (Computer Mediated Communication), odnosno komunikacija posredstvom kompjutera počela da se koristi kao sredstvo za razgovor osamdesetih godina, ali da se ovakva vrsta komunikacije popularizovala početkom devedesetih godina (Baron 2008: 11, 17).
} 
Stamenković \& Vlajković 2011, Popović 2012, Wood et al. 2014) govore o njihovom štetnom uticaju na jezik, jer ovaj novi jezički varijetet, koji više liči na skup kodova i šifri, i odlikuje se gotovo telegrafskim stilom i neformalnim registrom, narušava gramatička pravila i dovodi do simplifikacije standardnog jezika usled korišćenja pojednostavljene gramatičke strukture. Po pravilu, jezik na internetu je kolokvijalan i neformalan, a karakterišu ga jednostavnost i kratkoća u pisanju (Pano 2008). Pored upotrebe skraćenica i kovanja novih reči, jezik korisnika aplikacija neretko karakteriše i izostavljanje interpunkcije, odsustvo dijakritičkih znakova, proizvoljna upotreba velikog slova, (pogrešno) sastavljeno pisanje reči, korišćenje elipse i upotreba žargona i oskudnog izbora leksike. Sve ovo na duže staze može prouzrokovati visok stepen polupismenosti, posebno kod adolescenata (Stamenković \& Vlajković 2011: 219). Navedeni aspekti koji karakterišu jezik korisnika aplikacija se mogu preslikati i na druga polja upotrebe pisanog jezika i povećati tendenciju učenika da usvajaju i koriste nestandardne oblike maternjeg jezika. Pored toga, ističu lingvisti (Gong \& Ooi 2008: 917), ova nova vrsta jezika, nalik slengu, više liči na govorni jezik, iako formalno jeste oblik pisanog jezika.

Na drugoj strani stoje lingvisti (Ling 2005, Shortis 2007, Crystal 2008, Tagliamonte \& Denis 2008, Farina \& Lyddy 2011) koji veruju da jezik tipičan za komunikaciju preko aplikacija ili društvenih mreža ne može ugroziti komunikacijske veštine govornika, niti imati negativni uticaj na razvoj veštine pisanja kod mlađe populacije. U knjizi Txtng: the Gr8 Db8 autor (Crystal 2008) ističe da, iako brojne prepoznatljive karakteristike skraćenica jesu novina $\mathrm{u}$ pisanom tekstu, upotreba skraćenih formi ne može negativno uticati na jezik i pismenost učenika, posebno od trenutka kada su deca u stanju da razlikuju formalni i neformalni jezik. Autor navodi i da u tipičnoj tekstualnoj poruci manje od $10 \%$ reči bude skraćeno, da odrasli češće koriste skraćenice nego deca, da učenici obično ne koriste skraćenice u domaćim zadacima i ispitima, kao i da upotreba skraćenica ne može biti uzrok lošeg pisanja, jer ljudi moraju da znaju kako se neka reč piše pre nego što pošalju tekstualnu poruku. Osim toga, navodi isti autor, skraćenice se, i van aplikacija i društvenih mreža, koriste decenijama i zbog toga se ne mogu smatrati novim jezikom (Crystal 2011: 5). Stoga, iako su skraćenice dale novu dimenziju upotrebi jezika, njihov uticaj neće štetiti jezičkim 
standardima na duže staze. ${ }^{3}$ Lingvisti (Shortis 2007, Baron 2008, Crystal 2008) ističu da ne treba zanemariti kreativni potencijal ove vrste jezika, jer se kroz upotrebu skraćenica manifestuje inventivna upotreba slova, brojeva i interpunkcijskih znakova. Pored toga, nove skraćenice nastaju svakodnevno i svaki korisnik može da aktivno učestvuje u njihovom građenju.

Činjenica je da interakcija preko aplikacija ne daje previše vremena za opširno pisanje, te je korišćenje skraćenica logična posledica brze razmene mišljenja i potrebe za efikasnom razmenom informacija, budući da se ona gotovo uvek odvija u realnom vremenu gde sagovornik čeka poruku na koju treba da odgovori. Stoga su skraćenice, kao ortografske varijacije, postale uobičajeni sistem komunikacije mladih ljudi u digitalnom kontekstu.

\section{KORPUS I UČESNICI}

Korpus je sačinjen od poruka koje su mladi u Španiji, Italiji i Srbiji razmenjivali preko aplikacija Whatsapp i Viber. Ove dve aplikacije, osmišljene za pametne telefone, dozvoljavaju korisnicima razmenjivanje poruka, glasovne i video-pozive i slanje multimedijalnih sadržaja i predstavljaju najčešće korišćene aplikacije ovog tipa sa preko tri milijarde korisnika širom sveta. ${ }^{4}$

Informatori su bili izvorni govornici jezika, starosne dobi između 16 i 17 godina, učenici srednjih škola u Španiji (IES Fernando III grad, Martos), Italiji (Liceo Classico „N. Carlomagno”, Lauria) i Srbiji (XII beogradska gimnazija, Beograd). Broj učenika u istraživanju bio je sledeći: 25 u Španiji (14 učenika i 11 učenica), 33 u Italiji (6 učenika i 27 učenica) i 25 u Srbiji (13 učenika i 12 učenica). U cilju dobijanja što relevantnijeg uzorka u korpus je priključena $i$ prepiska još 26 osoba, poznanika i članova porodice autorke rada. Šest govornika španskog (4 mladića i 2 devojke), deset govornika italijanskog (5 mladića i 5 devojaka) i deset govornika srpskog (5 mladića i 5 devojaka), starosti između 20 i 25 godina i različitih obrazovnih profila takođe su učestvovali u istraživanju. Dakle, na raspolaganju smo imali poruke 109 mladih iz tri zemlje. Ipak, nemamo uvid u to koliki je bio ukupan broj svih učesnika u komunikaciji, odnosno broj

${ }^{3}$ „Neki ljudi ne vole pisanje poruka. Neke zbunjuje. Neki vole. Mene fascinira, jer je to najnovija manifestacija ljudske sposobnosti da bude jezički kreativna i da jezik prilagodi potrebama različitih okolnosti. Pisanje poruka delom reflektuje evoluciju jezika" (prevod autora, Crystal 2008: 175).

${ }^{4}$ Izvor: https://www.whatsapp.com/ i https://www.viber.com/ 
onih sa kojima su učesnici istraživanja razmenjivali poruke. Informatorima je dozvoljeno da sami naprave selekciju poruka koje će dati na analizu, odnosno imali su mogućnost da izostave previše lične poruke, iako je istraživanje bilo anonimno.

Induktivnim pristupom i metodom analize korpusa dobijen je uvid u jezik koji se upotrebljava tokom komunikacije putem aplikacija.

\section{ANALIZA KORPUSA}

Prema definiciji koju daje Rečnik španskog jezika Španske kraljevske akademije (DRAE) pod pojmom skraćenica podrazumeva se „proces redukovanja reči ili složenog izraza eliminacijom određenih slova ili slogova”.

Analizom sakupljenog korpusa izdvojili smo najčešće skraćenice koje koriste mladi u Španiji, Italiji i Srbiji s ciljem da ustanovimo da li u mehanizmu stvaranja skraćenica postoje sličnosti između tipološki srodnih jezika (španski i italijanski) i tipološki udaljenih jezika (srpski u odnosu na italijanski i španski jezik).

Skraćenice, koje u svim navedenim slučajevima služe da poruka bude što konciznija, izdvojene su u korpusu na sva tri jezika na osnovu autorove sprovedene analize i klasifikovane prema načinu obrazovanja. Utvrđeno je da među najučestalije tipove skraćenica spadaju: elizija, apokopa, inicijalizmi i akronimi, alfanumeričke kombinacije sa fonološkom vrednošću, kombinacija simbola i slova, korišćenje samo jednog slova, broja ili simbola kao zamena za celu reč, korišćenje nepostojećeg slova u alfabetu svakog od jezika, paragoga i anglicizmi.

\subsection{Elizija}

Elizija predstavlja izostavljanje vokala i korišćenje isključivo konsonanata jedne reči. Analizom skraćenica u korpusu na sva tri jezika dolazi se do zaključka da se najčešće radilo o medijalnoj i finalnoj eliziji.

Srpski jezik:

brt - brat ili brate; brv - bravo; cmk - cmok; dbr - dobro; dns - danas; fzn - fazon; hvl - hvala; inc - inače; jsm - jesam; kprm - kapiram; krtcn - kritično; lzs

${ }^{5}$ https://dle.rae.es/abreviaci\%C3\%B3n?m=form 
- lažeš; mn - mene ili meni; mng - mnogo; mrm - moram; mslm - mislim; nmj nemoj; nrvn - naravno; nsm - nisam; nst - ništa; rln - realno; skl - škola; smr smor; str - sutra; stvrn - stvarno; tbr - tebra; vcrs - večeras; znc - znači; zns znaš. ${ }^{6}$

U korpusu na srpskom postoji i nekoliko primera korišćenja samo pojedinih, a ne svih konsonanata iz reči:

msm - mislim; plj - paljba; svj - svejedno; vrv - verovatno; vzd Voždovac.

Osim navedenih, postoje i primeri pravljenja skraćenica od konsonanata nekoliko reči:

bzv ili bzvz - bez veze; cjms - čujemo se; lkn - laku noć; nmg - ne mogu; nmp - nemam pojma; nmvz - nema veze; nshvts - ne shvataš; nvrjm - ne verujem; nznm ili nzm - ne znam; str? - šta radiš?; zzms - zezam se.

Italijanski jezik:

bll - bello; bn - bene; bsgn - bisogno; cm - come; cn - con; cpt - capito; cs - cosa; dmn - domani; dp - dopo; dr - dire; drt - dirti; dv - dove ili devo; frs forse; grz - grazie; nmr - numero; nn - non; nnt - niente; qlcs - qualcosa; qll quello; qnd - quando ili quindi; qnt - quanto; qst - questo; scs - scusa; sl - solo; smpr - sempre; sn - sono; spr - sapere; tnt - tanto; trd - tardi; ttt - tutto; vgl voglia; vlv - volevo; vng - vengo.

I u italijanskom jeziku postoje primeri korišćenja samo pojedinih, a ne svih konsonanata iz reči prilikom građenja skraćenice:

cmq - comunque; dm - domani; msg - messaggio; nm - numero; pbl pubblico; pf - perfetto; prv - privato; pvt - privato (posebno u izrazu in pvt - in privato); qlc - qualcuno; qls - qualcosa; rsp - rispondi; trp - troppo; tt - tutto.

\section{Španski jezik:}

bbr - beber; bn - bien; brm - broma; bss - besos; bst - besito; bstnt bastante; bsts - besitos; cdt - ¡cuídate!; cm - cómo; cn - con; cnd - cuando; cnmg - conmigo; cntm! - ¡cuéntame!; dcr - decir; dfcl - difícil; dnd - donde; frt fuerte; fst - fiesta; ft - foto; fvr -favor; gns - ganas; gnt - gente; hcr - hacer; hcs haces; hr - hora; jdr - joder; jf - jefe; jnts - juntos; lgr - lugar; ls - los; mjr mejor; mntr - mentir; mñn - mañana; mtt - métete; $\mathrm{mx}$ - mucho ${ }^{7}$; nd - nada; pdrs

${ }^{6} \mathrm{U}$ korpusu na srpskom jeziku postoje i dva potpuno suprotna primera pravljenja skraćenica. Reč je o korišćenju samo vokala i izbacivanju konsonanata jedne reči: $a e-$ hajde i $e$-jel (e se smaras? - Je l' se smaraš?).

${ }^{7}$ Pogledati tačku 3.5. 
- podrás; pqñ - pequeño; ps - pues; sbs - sabes; slds - saludos; smpr - siempre; srt! - ;suerte!; st - este; td - todo; tng - tengo; trd - tarde; vms - vamos; vns? ¿vienes?; vrns - viernes. ${ }^{8}$

Kao i u srpskom i italijanskom jeziku, i u španskom postoje primeri korišćenja pojedinih, ne svih konsonanata iz reči:

cmplñ - cumpleaños; gcs - gracias; msj - mensaje; mv - móvil; ntcs entonces; prf -profesor; pq - porque; tb, tbn ili tmb - también; tbj - trabajo; tjt tarjeta; tl - teléfono; tp ili tmp - tampoco; vd ili vdd - verdad.

Pojava pravljenja skraćenica elizijom primećena je $\mathrm{u}$ sva tri jezika. Prilikom stvaranja i upotrebe ove vrste skraćenice učesnici su se verovatno vodili pravilom da konsonanti imaju jaču semantičku vrednost od vokala. Posebno španski i italijanski vokabular obiluju vokalima, ${ }^{9}$ tako da njihovo izbacivanje skraćuje vreme kucanja reči i na taj način ubrzava prenošenje poruke.

Komentarišući opisanu pojavu, Crystal ističe da skraćenice na internetu nisu konvencionalne već lične, i da je stoga moguće da se ista reč skrati na više različitih načina (2008: 45-46) (npr. msm ili mslm-mislim; tb ili tmb-también).

\subsection{Apokopa}

Apokopa predstavlja izostavljanje glasova na kraju reči. Slede primeri skraćenica nastalih korišćenjem samo početnih slova (konsonanata i vokala) jedne reči:

Srpski jezik:

bukv - bukvalno; dog - dogovor ili dogovoreno; geo - geografija; info informacija; insta - Instagram; iskr - iskreno; ist - istorija; komp - kompjuter; kr - kredit; mat - matematika; mik - mikrofon; mob - mobilni; muz - muzičko; nap - napolje; odg - odgovori; ozb - ozbiljno; opus - opušteno; por - poruka; poz pozdrav; prod - prodavnica; rodit - roditeljski; sk ili sko - škola; sl - sledeći ili slika; srp - srpski; stv - stvarno; sup - super; sut - sutra; tab - tablet; tel - telefon; udzb - udžbenik; ustv - u stvari.

Italijanski jezik:

\footnotetext{
${ }^{8}$ Česti primeri u korpusu na španskom jeziku jesu skraćenice bno - bueno, cmo - como; crño - cariño, csa - casa, pco - poco, gde je izvršena elizija, ali ne svih vokala u reči.

${ }^{9}$ Izvor:http://www.treccani.it/enciclopedia/immagine-dell-italiano_(Enciclopediadell'Italiano)/; http://lorien.die.upm.es/ lapiz/e-rthabla/numeros/N1/N1_A4.pdf
} 
amo - amore; anda - andare; ape - aperitivo; appunt - appuntamento; asp - aspetta; cel ili cell - cellulare; cia - ciao; disc - discoteca; dom ili doma domani; fav - favore (u izrazu: $x$ fav - per favore); fra ili frat - fratello; info informazione; lune - lunedì; ma- mamma; mess - messaggio; ness - nessuno; pa papà; prof - professore; raga - ragazzi; rip - ripeti; risp - rispondi; sab - sabato; scem - scemo/a; ser - sera; sett - settimana; so - sono; stas - stasera; tel telefono; trnqui - tranquillo/a; veng - vengo.

Španski jezik:

cl - claro; do - domingo; ej - ejemplo; exam - examen; fa - favor; Face Facebook; fam - familia; fav - favorito; fin - final; finde - fin de semana; info información; ju - jueves; lu - lunes; ma - mamá; nos - nosotros; obv - obvio; pa papá ili para; peli - película; pier - pierdo; pos - posible; porq - porque; profe profesor; pued - puedo; recu - recuperación; va - vale; vac - vacaciones; vos vosotros.

Osim skraćivanja slogova jedne reči, zabeleženi su i slučajevi skraćivanja u poslednjoj reči izraza npr: ustv - u stvari, finde - fin de semana.

Navedena pojava je u lingvistici poznata i pod nazivom dekstralna abrevijacija, odnosno slučaj kada skraćenica nastaje od početnih slova reči koja se krati.

U korpusu na srpskom jeziku zabeležen je i suprotan fenomen, odnosno afereza ili sinistralna abrevijacija, u primerima đa - sviđa, fon - telefon i net internet, gde je došlo do izostavljanja glasova na početku reči. Tri primera afereze pronađena su u španskom jeziku: amos - vamos; enga - venga; stoy - estoy i dva u italijanskom jeziku: na - una; sto - questo.

\subsection{Inicijalizmi i akronimi}

Inicijalizmi su skraćenice nastale od početnih slova više reči, pri čemu se slova novonastale složenice izgovaraju posebno. Akronimi su skraćenice kod kojih se dve ili više reči redukuju na njihova početna slova, a da se pritom novonastala složenica može izgovoriti kao celovita, samostalna reč.

Stvaranje skraćenica korišćenjem početnog slova svake reči omogućava korisniku aplikacija da u tek nekoliko slova iskaže sadržaj čitave rečenice. Ovaj fenomen svojstven je svim analiziranim jezicima.

Srpski jezik:

amr - ako me razumeš; app - ako prođe, prođe; avs - (h)ajde vidimo se; ckz - cimaj kad završiš; cspsv - čujemo se, pa se vidimo; dd - dobar dan; gsp gledaj svoja posla; ks? - kako si?; ln - laku noć; nnc - nema na čemu; np - nema 
problema ili nemam pojma; nz - ne znam; pgv - potpuno gubljenje vremena; pmsm - po mom skromnom mišljenju; sbbkbb - šta bi bilo kad bi bilo; sn - sve najlepše; sr - srećan rođendan; sr? - šta radiš?; tf - taj fazon; tjt - to je to; ttk - to ti kažem; ubr - uzgred budi rečeno; vsk - vraćam se kasnije/ kasno; vtnncs volim te najviše na celom svetu; vt - volim te; vtp - volim te puno.

Italijanski jezik:

ad - a domani ili a dopo; ap - a presto; cv ? - come va?; cvd - ci vediamo dopo; $\mathrm{mmt}$ - mi manchi tanto; msm - mi sei mancato/a; nc - nessun commento; $\mathrm{np}$ - nessun problema; pf - per favore; tat - ti amo tanto; to - ti odio; tvb - ti voglio bene; tvbtt - ti voglio bene tanto tanto; tvtb - ti voglio tanto bene; tvttb - ti voglio tanto tanto bene; $v b$ - va bene.

\section{Španski jezik:}

asc - al salir de clase; bhl - bueno hablamos luego; bn - buenas noches; cc - cuenta conmigo; hdp ili hp - hijo de puta; hdspm - hijo de su puta madre; hl - hasta luego; ls - lo sé; mcl - me cuentas luego; mg - me gusta; mq ili mk? ¿me quieres?; nlc - no lo conozco; nls - no lo sé; nph - no puedo hablar; npn - no pasa nada; ns - no sé; nsn - no sé nada; ntc ili ntk - no te creas; ntp - no te preocupes; ntr - no te rayes; nv - nos vemos; nva - nos vemos allí; nvm - nos vemos mañana; pf - por favor; pq - por qué; qmd? - ¿qué me dices?; ss - Semana Santa; stld - si tú lo dices; tq - te quiero; tkm ili tqm - te quiero mucho; to - te odio; tpp - te pido perdón; tvl - te veo luego.

Smatramo da je upotreba inicijalizama i akronima veoma česta $u$ interakciji preko aplikacija, jer ovaj tip skraćenica služi da se redukuje dužina poruke, da se uštedi vreme i izrazi što više informacija sa što manje teksta (jezička ekonomija). Vrlo često, kako primećuje Klajn (2002: 165), neretko se skraćenice, pošto uđu u upotrebu, potpuno osamostaljuju i postaju prepoznatljivije i poznatije nego pun oblik.

\subsection{Alfanumeričke kombinacije sa fonološkom vrednošću}

Korisnici aplikacija, pored teksta u poruku koju šalju često ubacuju i brojeve, čime se stvara specifičan oblik komunikacije, nalik kodovima ili šiframa. Alfanumeričke kombinacije sa fonološkom vrednošću nastale ovakvom vrstom supstitucije, odnosno skraćenice nastale kombinovanjem slova i brojeva identifikovane su u sva tri jezika.

Srpski jezik:

ni1 - nijedan; 2put - dvaput; o2lio - odvalio; 3k - trik; 3pujes - tripuješ; u3povati - utripovati; 4tak - četvrtak; 5ak - petak; 5ar - Petar; 5oro - petoro; 
5rović - Petrović; 5sop - pet šop; 5sto - petsto; o5 - opet; reka8 - rekao sam; stiga8 - stigao sam; zuri8 - žurio sam; 100janovic - Stojanović; 100ka - stoka.

Italijanski jezik:

qlc1 - qualcuno; nes1 - nessuno; tv1mdb - ti voglio un mondo di bene; 3 mendo - tremendo; 3no - treno; c6? - ci sei?; dv 6? - dove sei?; k6? - chi sei?; $7 \mathrm{mbre}$ - settembre; s8 - sotto; 8 bre - ottobre, r8 - rotto; 80 - ho tanta (voglia di...).

\section{$\underline{\text { Španski jezik: }}$}

10 - primero; $1 \mathrm{r}$ - primer; d2 - dedos; salu 2 - saludos; to 2 - todos; es 3 estrés; 100pre - siempre; 100to - siento.

U srpskom jeziku najviše su korišćeni brojevi 3 (tri) i 5 (pet) kako bi, uz slova uz koja stoje, dali reči istu fonološku vrednost koju ta reč ima kada se izgovara. U italijanskom jeziku najčešće je broj 3 (tre) korišćen u rečima u kojima se čije glas tre (tremendo, treno), potom 6 ( $\mathrm{sei}$ ) kao zamena za drugo lice jednine glagola essere (biti) koje se izgovara na isti način i broj 1 (uno), koji nekad menja broj jedan ili neodređeni član un/ uno/ una (tv1mdb) a nekad menja izgovor reči uno (nes 1). U španskom jeziku korišćen je najčešće broj 2 (dos) u rečima čiji se jedan slog izgovara upravo tako (todos, saludos) ili broj jedan (1) koji se u skraćenicama izgovarao kao redni broj (primer/o).

Neke skraćenice su kombinacije više njih, npr: k6? (korišćenje nepostojećeg slova u alfabetu i alfanumerička kombinacija), qlcl (elizija vokala i alfanumerička kombinacija).

U korpusu su pronađeni brojni primeri ovakve neografije. U svim slučajevima postignuta je fonetska transkripcija.

\subsection{Kombinacija simbola i slova}

Logogrami su bilo koja vrsta slova, znaka ili simbola koji se koriste za predstavljanje cele reči. ${ }^{10}$ To su i matematički simboli kao $\square, \square$, =, simbol za procenat $\square$, oznake valuta npr. £, engleski znak $\square$ itd. (Bugarski 2009: 51). Slično kao i kod alfanumeričkih kombinacija, kod ove vrste skraćenica reči su obrazovane upotrebom simbola ili grafičkih jedinica čiji izgovor zvuči kao jedan slog te reči ili cela reč.

${ }^{10}$ Izvor: https://www.collinsdictionary.com/dictionary/english/logogram 
Torlak smatra da se sa pojavom interneta nekada složen sistem znakova, slova, reči, rečenica i pravila redukovao na ono odakle je počela pismenost, a to je „crtanje slika kako bi se predstavilo značenje“ (Torlak 2013: 367).

Srpski jezik:

U korpusu na srpskom jeziku nije bilo primera za ovu vrstu skraćenica.

Italijanski jezik:

xché - perché; xciò - perciò; xdere - perdere; xdonare - perdonare; xfetto - perfetto; xm - per me; xò - però; xso - perso; xsona - persona; axetivo aperitivo; saxe - sapere; suxbo - superbo; sxo - spero; + o - - più o meno; +mino - piumino; +ttosto - piuttosto; al - - almeno; - male - meno male; a. - appunto; a.. - appunti; in + insomma; tutto + to - tutto sommato; $\| \mathrm{m}-$ secondo me; $\mathrm{nn}+€$ non ho (avevo) più soldi;

Španski jezik:

+ a - masa; ad +- además; d+ - demás; gral\% - generalmente; xa - para; xdon - perdón; xlo - - por lo menos; xo - pero; xq - por qué.

Ovakvi primeri parcijalne ili potpune supstitucije (logogrami) zabeleženi su u korpusu na italijanskom i španskom jeziku.

Najkorišćeniji simbol u skraćenicama u italijanskom jeziku jeste $x$ koji se u matematici izgovara kao per i označava množenje. Često upotrebljavan je i simbol + koji u matematici označava sabiranje i izgovara se kao più. Isti simbol korišćen je i da zameni reč somma - zbir, sabiranje. Primećena je i upotreba simbola - koji u matematici označava oduzimanje, minus i izgovara se kao meno. Simbol tačke (.) korišćen je da zameni reč punto kako se ovaj simbol i izgovara.

Nisu izostale kombinacije više skraćenica: xqlc1 - per qualcuno (kombinacija simbola i slova, alfanumerička kombinacija i korišćenje elizije), zatim $x f v$ - per favore ili + trd - più tardi (kombinacija simbola i slova i korišćenje konsonanata bez vokala, odnosno elizije).

U španskom jeziku najkorišćeniji simbol jeste + koji u matematici označava sabiranje i izgovara se kao más. Simbol $x$, korišćen u matematici da označi množenje, menjao je reči para ili por, i najčešće izgovor reči per. Slično kao u italijanskom, simbol za oduzimanje - menjao je reč menos. U španskom jeziku primećen je još jedan primer supstitucije: simbol/ slovo $x$ korišćeno je i kao zamena za digram $c h$. Slovo $x$ postoji u španskom alfabetu, ali je njegov izgovor [ks] ili [ys]: xat - chat; xatr - chatear; maxo - macho; mxо ili muxo - mucho; noxes - noche. ${ }^{11}$

${ }^{11}$ Slično tome slovo $y$ je menjalo $l l$ : cyat - cállate; yamm - llámame; yav - llave. 
Ni u španskom jeziku nisu izostale kombinacije skraćenica: $x q$-porque (kombinacija simbola i slova, elizija i korišćenje samo jednog slova umesto cele reči), $m x-m u c h o$ (korišćenje supstitucije i elizija vokala).

\section{6. Korišćenje samo jednog slova, broja ili simbola kao zamena za celu reč}

Izvorni govornici španskog, italijanskog i srpskog jezika, u prepisci preko aplikacija često koriste i logograme, odnosno samo jedno slovo, broj ili simbol da zamene celu reč. U romanskim jezicima svaki graf ima određeni naziv (npr. italijanski $c$-ci). Korisnici skraćenica često koriste ovu činjenicu kako bi slovom zamenili celu reč koja se izgovara kao naziv tog slova. U italijanskom i španskom jeziku speling slova alfabeta ova dva jezika dozvoljava veću kreativnost pri stvaranju skraćenica nego u srpskom jeziku.

Srpski jezik:

c - ćao; d - da; dj - đubre; dz - džabe; $n$ - ne; nj - nju; $p$ - pozdrav; $r$ razred; z - zdravo ili zovi.

\section{Italijanski jezik:}

+ - più; 1 - una; 6 - sei; c - ci; c - ciao; d - di; $\mathrm{k}$ - che; m o f? maschio o femmina?; s - sì; s o f? solo (single) o fidanzato/a?; $\mathrm{t}$ - ti; $\mathrm{x}$ - per (predlog), w! viva!/ evviva!

\section{Španski jezik:}

- -menos; + - más; = - igual; $\mathrm{b}$ - beso; $\mathrm{c}$ - sé; $\mathrm{d}$ - de; $\mathrm{h}$ - hombre; $\mathrm{k}$ - que; $\mathrm{m}$ - mujer; $\mathrm{m}$ - me; $\mathrm{n}$ - en; $\mathrm{n}$ - no; $\tilde{\mathrm{n}}$ - año; $\mathrm{q}$ - que; $\mathrm{r}$ - responde; $\mathrm{s}$ - es; $\mathrm{t}$ - te/tu; $\mathrm{x}$ - por ili para.

U italijanskoj korespondenciji putem aplikacija često se koristi simbol $x$ kao zamena za predlog per (kako se ovaj simbol i izgovora). Isti simbol je korišćen (tačka 3.5.) i u svim rečima čiji se jedan slog izgovara kao per (xdonare, xfetto). Slovo $t$ (čiji je naziv u alfabetu $t i$ ) u skraćenicama je označavalo dativne, akuzativne ili povratne zamenice drugog lica jednine koje imaju isti izgovor ( $t$ penso - ti penso). Slovo $d$ (čiji je naziv u alfabetu $d i$ ) menjalo je italijanski predlog $d i$ koji se izgovara na isti način ( $d d v 6$ ? - di dove sei?). Slovo $c$ (čiji je naziv u alfabetu $c i$ ) odnosilo se na rečcu $c i$ ( $c 6$ ? - ci sei?). Broj 6 (koji se izgovara kao sei) koristio se kao drugo lice jednine glagola essere (biti), npr. dv6? - dove sei?, 6 bellissma - sei bellissima.

U španskom jeziku slovo $q$ je menjalo reč que koja je imala različita značenja u rečenici, s obzirom na kontekst. Slično je upotrebljavano i slovo $k$ koje ima istu fonetsku vrednost kao digram $q u$, ali ga je lakše i brže napisati; matematički znak $x$ je korišćen umesto uzročnog predloga por ili namernog 
predloga para, dok su simboli $+\mathrm{i}$ - menjali reči más i menos (no puedo + , te echo de -). Shodno tome, simbol $=$ menjao je reč igual (jednako, isto).

Zajednička karakteristika navedenih skraćenica jeste česta fonetska supstitucija digrama ili trigrama, npr. italijanski: $k$ umesto che, ili španski $q$ umesto que.

Druga zajednička karakteristika korišćenja samo jednog slova, broja ili simbola kao skraćenice u sva tri jezika bila je ta da su oni korišćeni u širem rečeničnom kontekstu zahvaljujući kome se nepogrešivo moglo zaključiti šta znače.

\section{7. Korišćenje nepostojećeg slova u alfabetu svakog od jezika}

Korisnici aplikacija, u pravljenju skraćenica na sva tri analizirana jezika, koristili su slova nepostojeća u sopstvenom alfabetu:

Srpski jezik:

bkw ili bukw - bukvalno; hwl - hvala; wrw - verovatno; wtp - volim te puno; wzd - Voždovac; xtra - ekstra; qq - kuku; laq - laku (noć); ql - kul; ncy neću; slyc - slučajno.

Italijanski jezik:

k ili ke - che; ki - chi, km - come; kn - con; ks - cosa; qlk - qualche; qlks - qualcosa; dx - destra; ex - esempio; sx - sinistra; poxo - posso; prox prossimo/a; w! - viva!/ evviva!

\section{Španski jezik:}

wno - bueno; wnas - buenas; wpa - guapa; iwal - igual.

$\mathrm{U}$ italijanskom je često upotrebljavan graf $x$ koji ne postoji u italijanskom alfabetu (osim u rečima stranog porekla) bilo kao zamena za slovo $s$, bilo kao zamena za udvojeno slovo $s$. Razlog može biti to što je latinsko $x$ u italijanskom jeziku postalo ss. Najčešće upotrebljavani graf koga nema u italijanskom alfabetu jeste $k$ u onim rečima kada se čuje izgovor $k$, a piše se digram $c h$.

Primećena je i kombinacija različitih mehanizama građenja skraćenica: $x k e ́$ - perché (korišćenje simbola i slova nepostojećeg u italijanskom alfabetu), qlk - qualche (elizija vokala i korišćenje slova nepostojećeg u italijanskom alfabetu).

U španskom jeziku najčešće korišćeno nepostojeće slovo bio je konsonant $w$ kao zamena za $b u$ ili $g u{ }^{12}$

${ }^{12}$ Premda se slovo $W$ nalazi u španskom alfabetu, koristi se isključivo u pisanju reči stranog porekla, pa se ne može smatrati pravim španskim slovom. 
Treba pomenuti da ista reč može biti skraćena na više različitih načina, npr. španska reč igual skaćivana je kao: iwal (korišćenje nepostojećeg slova) ili kao simbol $=($ videti tačku 3.6.) .

\section{8. Paragoga}

Paragoga jeste fenomen dodavanja slova ili sloga na kraju reči. U primerima iz korpusa primećena je reduplikacija konsonanata, nepostojećeg u originalnoj reči:

Srpski jezik:

ness - nešto; niss - ništa; nezz - ne znam; pozz - pozdrav

Italijanski jezik:

gg - giorni; pp - pagine.

Španski jezik:

dd - días; $\mathrm{mm}$ - meses; rrss - redes sociales.

Konsonanti su se udvajali sa različitim ciljem. U srpskom jeziku udvojeno $s$ označavalo je slovo $\check{s}$. Naime, budući da za pisanje poruka uglavnom koriste englesku tastaturu, srpski govornici često umesto korišćenja dijakritičkih znakova pribegavaju udvajanju slova, odnosno koriste udvojena slova umesto slova sa znakom.

U italijanskom i španskom jeziku udvojeni konsonant označavao je množinu reči. Osim navedenog, čini se da ne postoji precizno utvrđeno pravilo za upotrebu ove vrste fonetske redundance. Moguće je da je razlog, kao i u prethodnim slučajevima skraćenica, jezička ekonomija uslovljena brzinom komunikacije na internetu ili privlačenje pažnje sagovornika.

\section{9. Anglicizmi}

Engleski, jedan od tri najrasprostranjenija svetska jezika, ${ }^{13}$ smatra se međunarodnim jezikom komunikacije i informacionih tehnologija, tako da ne čudi njegov snažan uticaj na druge jezike. Često govornici pribegavaju engleskom jeziku (kao lingua franca) u situacijama kada u maternjem ne uspevaju da nađu odgovarajuće reči, ili im doslovan prevod engleske reči na maternji ne zvuči dobro ili prirodno.

\section{Srpski jezik:}

${ }^{13}$ Izvor: https://sr.wikipedia.org/sr-/sr-ec/Списак_језика_по_броју_говорника 
bb (bye, bye) ${ }^{14}$ - baj baj; b-day (birthday) - rođendan; bff (best friends forever) - najbolji prijatelji zauvek; btw (by the way) - uzgred, usput; fyi (for your information) - za tvoju informaciju; ily (I love you) - volim te; lol (laughing out loud) - grohotom se smejem; ok (all correct) - u redu; pls (please) - molim te; sry (sorry) - izvini; thanx ili thx (thanks) - hvala; tia (thanks in advance) - hvala unapred.

Italijanski jezik:

allH - allora; xh - per ora; b4 (before) - prima; idk (I don't know) - non lo so; jk (just kidding) - sto/ stavo scherzando; 18r (later) - più tardi; obv (obvious) - ovio; ok (all correct) - va bene; pls/ plz (please) - per favore; smh (shaking my head) - scuotere la testa; sos (save our souls/ ship) - aiuto; tbh (to be honest) - ad essere sinceri/ onesti; thx/ tnx (thanks) - grazie; we (weekend) - fine settimana; wht? (what?) - cosa?

Španski jezik:

$4 \mathrm{u}$ (for you) - para ti; b4 (before) - antes; cu (see you) - nos vemos; $\mathrm{Fb}$ Facebook; Ig - Instagram; lol (laughing out loud) - reír en voz alta; ok (all correct) - está bien, vale; rt (ReTweet ) - suscribo tus palabras; sry (sorry) - perdón; Wa WhatsApp.

U sva tri jezika primećena je upotreba globalno korišćenih engleskih skraćenica poput: ok, FB, sos. U italijanskom korišćen je graf $h$ koji u engleskom označava sat, onda kada je u italijanskom trebalo da se upotrebi reč ora (sat), npr: allh (allora).

$\mathrm{Ne}$ iznenađuje što se skraćenice engleskih reči, konstrukcija i izraza koriste u sva tri posmatrana jezika. Naučnici smatraju razvoj interneta zaslužnim za razvoj jezičke revolucije koja je govorni i pisani jezik zamenila novim medijumom, pri čemu je ključnu ulogu odigrao engleski jezik koji je kao globalni jezik doveo do svetske dominacije plurilingvalizma (Crystal prema Stamenković \& Vlajković 2011: 213). Pored toga, preuzimanje reči iz drugih jezika predstavlja najčešći način proširivanja rečnika maternjeg jezika (Bugarski 2003: 174).

\section{ZAKLJUČAK}

Pojava interneta i razvoj tehnologije u potpunosti su promenili obrasce društvenog života, a samim tim uticali su i na modifikaciju jezika i način komunikacije. Korišćenje aplikacija i društvenih mreža, koje su postale

${ }^{14} \mathrm{U}$ zagradama se nalaze engleske reči koje su skraćene. 
najkorišćeniji komunikacijski kanali, pretežno među mlađom populacijom, doprinelo je stvaranju potpuno novog jezika koji odstupa u velikoj meri od standardnog, književnog jezika. U početku s ciljem redukovanja teksta poruke zbog ograničenog broja znakova u SMS-u, a kasnije zbog brzine pisanja poruke, korisnici aplikacija stvorili su novi jezik koji obiluje skraćenicama. Lingvisti nisu saglasni u stavu kakav uticaj ovaj novi jezički kod ima na pismenost kod mladih ljudi. Pojedini veruju da je on uzrok visokog stepena polupismenosti, dok drugi tvrde da ove nove reči jesu odraz inventivnosti mladih, da obogaćuju jezik i da na duže staze ne mogu negativno uticati na standardni jezik, već da, naprotiv, doprinose boljoj komunikaciji među korisnicima. Izvesno je, međutim, da su skraćenice, kao nova forma komunikacije, sastavni i nezaobilazni deo interakcije putem aplikacija, zbog kojih su i stvorene. One korisnicima dozvoljavaju korišćenje malog broja znakova, odnosno jezičkih jedinica za prenošenje poruke. Radi se o jezičkoj ekonomiji koja ubrzava komunikaciju tokom interakcije putem aplikacija.

Iako stvaranje i korišćenje skraćenica u pisanoj komunikaciji nije novina, njihova učestalost i kreativnost doprinele su da skraćenice postanu najupečatljivije obeležje jezika koji se koristi u aplikacijama i na društvenim mrežama. Razlozi zbog kojih korisnici aplikacija koriste skraćenice jesu ušteda vremena, mogućnost da se izrazi što više sa što manje reči, a možda i činjenica da mladi očekuju jedni od drugih da prate ovakvu vrstu trenda.

Rezultati su pokazali da korisnici aplikacija koriste skraćenice prilikom onlajn interakcije, kao i da koriste iste mehanizme za građenje skraćenica bez obzira na njihov maternji jezik. U najčešće skraćenice spadaju elizija, apokopa, inicijalizmi i akronimi, alfanumeričke kombinacije, logogrami, paragoga i anglicizmi. Zajedničko svim skraćenicama jeste da su pretrpele neku vrstu promene u morfologiji u odnosu na normu standardnog jezika. Druga zajednička karakteristika jeste da je skraćenica uvek prepoznatljiva i nikada ne ometa razumevanje poruke. Dakle, pošiljalac i primalac poruke umesto standardnog jezika koriste transformisani kod i, premda se svakodnevno stvaraju nove skraćenice, gotovo uvek su u stanju da razumeju značenje poruke. Zajedničko za sve jezike je i to da su skraćenice često nastajale kombinacijom više različitih mehanizama građenja skraćenica.

I kod tipološki srodnih jezika (španski i italijanski) i kod jezika koji to nisu (srpski u odnosu na dva pomenuta romanska jezika) princip stvaranja i 
upotrebe skraćenica je isti, a skraćenice u sva tri jezika dele slične karakteristike koje ovaj fenomen čine interjezičkim i interkulturalnim.

\section{LITERATURA}

Baron, N. (2008). Always on: Language in an Online and Mobile World. Oxford: Oxford University Press.

Bugarski, R. (2003). Uvod u opštu lingvistiku. Beograd: XX vek.

Bugarski, R. (2009). Pismo. Beograd: Čigoja.

Crystal, D. (2008). Txtng: The Gr8 Db8. Oxford: Oxford University Press.

Crystal, D. (2011). Internet Linguistics: A student Guide. UK: Routledge.

Eco, U. (2011). "Il garibaldino Nino Biperio". <https://espresso.repubblica.it/ opinioni/la-bustina-di-minerva/2011/03/31/news/il-garibaldino-ninobiperio-1.30010?refresh_ce> (Pristupljeno: 25. 01. 2020.)

Farina F. \& F. Lyddy (2011). "The Language of Text Messaging: 'Linguistic Ruin' or Resource?".

URL:<https://www.researchgate.net/publication/277009101_The_Language_of_T ext_MessagingLinguistic_Ruin_or_Resource> (Pristupljeno: 24.11. 2019.)

Gong, W. \& Ooi, V. (2008). "Innovations and motivations in online chat". Handbook of research on computer mediated communication, eds. S. Kelsey. \& K. St. Amat (London: Information Science Reference), 917-933.

Kern, R. (2006). "Perspectives on Technology in Learning and Teaching Languages". TESOL Quarterly 40(1), 183-210.

Klajn, I. (2002). Tvorba reči u savremenom srpskom jeziku. Deo 1. Slaganje $i$ prefiksacija. Beograd: Zavod za udžbenike i nastavna sredstva.

Ling, R. (2005). "The socio-linguistics of SMS: An analysis of SMS use by a random sample of Norwegians". <https://www.researchgate.net/ publication/226933560_The_Sociolinguistics_of_SMS_An_Analysis_of_ SMS_Use_by_a_Random_Sample_of_Norwegians> (Pristupljeno: 03. 12. 2019.)

Pano, A. (2008). "Dialogar en la Red. La lengua española en chats, e-mails, foros $\mathrm{y}$ blogs". <https://www.academia.edu/2492236/Dialogar_en_la_Red._La_lengua_es pa\%C3\%B1ola_en_chats_e-mails_foros_y_blogs> (Pristupljeno: 26. 01. 2020.)

Popović, I. (2012). "Integenerational communication problems caused by the influence of social networks". Informatologia 45 (4), 333-341.

Radić Bojanić, B. (2007) Neko za chat?! Diskurs elektronskih ćaskaonica na engleskom srpskom jeziku. https://www.academia.edu/5352191/neko_za_chat_Diskurs_elektronskih_ 
\%C4\%87askaonica_na_engleskom_i_srpskom_jeziku (Pristupljeno: 26. 01. 2020.)

Rosen, L. D., Chang, J., Erwin, L., Carrier, M., \& Cheever, N. A. (2010). "The relationship between textisms and formal and informal writing among young adults". Communication Research 37(3), 420-440.

Shortis, T. (2007). "Gr8 txtpectations: the creativity of text spelling". https://worc.rl.talis.com/items/F01D81F0-6AC8-0E2E-E3D9-

53CCF3915DAC.html (Pristupljeno: 26. 12. 2019.)

Sirah, S. A. \& Ullah, F. (2007). "Postmodernism and Its Insinuations on Media and Society". <https://dialnet.unirioja.es/servlet/articulo?codigo= 3603972> (Pristupljeno: 26. 12. 2019.)

Stamenković, D. i Vlajković, I. (2011). „Jezički identitet u komunikaciji na društvenim mrežama u Srbiji“. Jezik, književnost, komunikacija, jezička istraživanja, ur. B. Mišić Ilic i V. Lopičić (Niš: Filozofski fakultet), 212224.

Tagliamonte, S. \& Denis, D. (2008). "Linguistic ruin? LOL! Instant messaging and teen language". American Speech 83(1), 3-34.

Thurlow, C. (2003). "GenerationTxt? The sociolinguistics of young people's textmessaging".

https://www.researchgate.net/publication/259258527_Generation_Txt_Th e_sociolinguistics_of_young_people's_textmessaging/link/56c5fc5708ae4 08dfe4ca641/download (Pristupljeno: 26. 11. 2019.)

Thurlow, C., Lengel, L. B. \& Tomic, A. (2004). Computer mediated communication: social interaction and the Internet. London: Sage.

Torlak, N. (2013). „Novi mediji - nova pravila i nova recepcija kulture i umjetnosti“. In medias res: časopis filozofije medija 2(3), 366-371.

Wood, C., Kemp, N., Waldron, S. \& Hart, L. (2014). "Grammatical understanding, literacy and textmessaging in school children and undergraduate students: a concurrent analysis". Computers \& Education 70, 281-290.

Marija N. Vujović

\section{MAIN CHARACTERISTICS OF ABBREVIATIONS USED IN COMMUNICATION THROUGH APPLICATIONS}

\section{Summary}

The appearance of the Internet and the development of technology have completely changed the patterns of social life, and thus have influenced the modification of language and the way of communication. The use of applications and social networks that have become the most used communication channels, predominantly among the younger population, has contributed to the creation of a completely new language that deviates 
greatly from the standard, literary language. Initially aimed at reducing the text of the message due to the limited number of characters in the sms, and later due to the speed of writing the message, application users created a new language that is full of abbreviations. Linguists disagree on the impact this new language code has on literacy among young people. However, it is certain that abbreviations are an integral and inevitable part of application interaction. This paper analyzes abbreviations made by native speakers of Spanish, Italian and Serbian. The results showed that application users use abbreviations when interacting online. They also use the same mechanisms to construct abbreviations regardless of their native language. The most common abbreviations include elision, apocope, initials and acronyms, alphanumeric combinations, logograms, paragogue and anglicisms. Common to all abbreviations is that they have undergone some sort of morphological change in regard to the standard language norm. Another common feature is that the abbreviations never interfere with the understanding of the message. What is common to all languages is that abbreviations are often created by the combination of several different mechanisms of construction of abbreviations. In both typologically similar languages (Spanish and Italian) and languages that are not typologically similar (Spanish and Italian compared to Serbian), the principle of making and using abbreviations is the same, and abbreviations in all three languages share similar characteristics that make this phenomenon interlingual and intercultural.

Key words: abbreviations, applications, Whatsapp, Viber, Internet, Spanish, Italian, Serbian 